\title{
STRUCTURAL RESEMBLANCE OF CYTOCHROME P-450 ISOLATED FROM PSEUDOMONAS PUTIDA AND FROM RABBIT LIVER MICROSOMES*
}

Karl Dus, William J. Litchfield, and Anne G. Miguel, Department of Biochemistry, University of Illinois, Urbana, Illinois 61801,

and

Theodore A. van der Hoeven, David A. Haugen,t William L. Dean,* and Minor J. Coon, Department of Biological Chemistry, Medical School, The University of Michigan, Ann Arbor, Michigan 48104

Received July 12,1974

Summary: The cytochrome $P-450$ of Pseudomonas putida $(P-450$ cam $)$ and that of phenobarbital-induced liver microsomes $(P-450 \mathrm{LM})$ differ markedly in substrate specificity, solubility, and the requirement of the former for an iron-sulfur protein and the latter for a phospholipid for hydroxylation activity. Despite these differences, highly purified $\mathrm{P}-450$ cam and $\mathrm{P}-450 \mathrm{LM}$ show immunological cross reaction by competitive binding and inhibition of catalytic activity and are of similar subunit molecular weight and amino acid composition. Upon treatment with cyanogen bromide they yield small heme-containing peptides of highly similar amino acid composition.

The unusual metabolic versatility, broad substrate specificity, and wide distribution of P-450 cytochromes raise the intriguing question of the extent to which these hemeproteins from various sources are structurally related. The soluble enzyme system of Pseudomonas putida which catalyzes the 5-exo hydroxylation of camphor was first described by Hedegaard and Gunsalus (1). $\mathrm{P}-450_{\text {cam }}$ was later identified as the monoxygenase $(2,3)$ and obtained in homogeneous, crystalline form (4), and the iron-sulfur protein putidaredoxin, was found to function as an electron carrier (5). The solubilization and resolution of the cytochrome P-450-containing enzyme system of 1 iver microsomal membranes into three components was first described by $L u$ and Coon (6). P-450LM has been partially purified in several laboratories (712) and recently obtained in a highly purified state from rabbit liver microsomes by van der Hoeven and Coon (13). The purified P-450LM differs from P450 cam in that it hydroxylates a variety of substrates, including drugs, fatty acids, alkanes, and aniline (13) and requires phosphatidylcholine for

* This research was supported by Grant GM-18902 from the National Institutes of Health to K.D. and Grants GB-30419X from the National Science Foundation and AM-10339 from the National Institutes of Health to M.J.C.

+ Postdoctoral Fellow, United States Public Health Service.

* Predoctoral Traineed, United States Public Health Service, Grant GM-00187. 
activity $(13,14)$. The microsomal enzyme system also differs from the bacterial enzyme system in not requiring an iron-sulfur protein as an electron carrier. This communication shows that the bacterial and liver microsomal P-450 cytochromes have surprisingly similar immunochemical and structural properties.

Materials and Methods: $P_{-}-450_{\text {cam }}$ crystallized as the camphor complex was generously provided by Dr. I. C. Gunsalus. It was of highest purity as judged by the absorbance ratio, $A_{391} / A_{280}=7.5$, and the amino acid composition $(4,15)$. The $P-450_{L M}$ purified from phenobarital-induced rabbit liver microsomes (13) was at a concentration of 13.3 nmoles per mg of protein. As shown in Fig. 1,

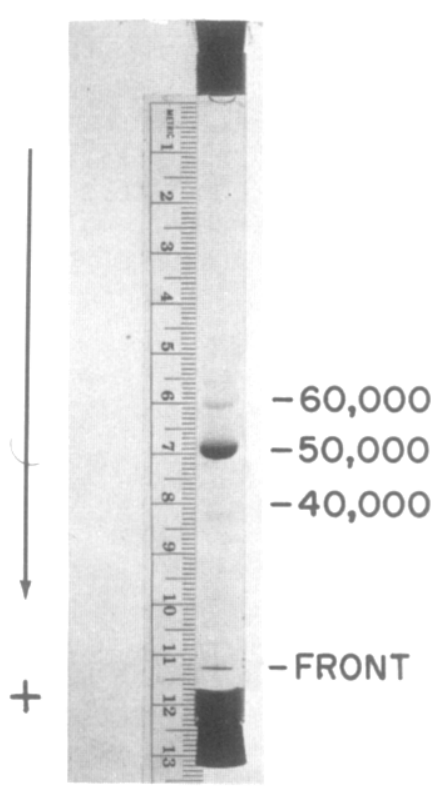

Fig. 1. SDS-polyacrylamide gel electrophores is of purified P-450LM. The electrophoresis of a 6- $\mu$ g sample of protein, previously treated with SDS and $\beta$-mercaptoethano 1 at $100^{\circ}$, was performed in a discontinuous buffer system (16) using $7.5 \%$ acrylamide. The gel was stained with Coomassie Blue and stored in $7 \%$ acetic acid, and the purity of the preparation was estimated from densitometer tracings at $550 \mathrm{rm}$. Molecular weight calibration with standard proteins and $\mathrm{P}-45 \mathrm{~L}_{\mathrm{LM}}$ both present was carried out in other gels.

SDS-polyacrylamide gel electrophoresis revealed a single major band accounting for about $90 \%$ of the protein.

Rabbit antisera to $\mathrm{P}-450_{\mathrm{Cam}}$ and $\mathrm{P}-45 \mathrm{C}_{\mathrm{LM}}$ were purified by ammonium sulfate precipitation $\left(0\right.$ to $25 \%$ ). The resulting anti-P-450 ${ }_{\text {cam }}$ antibody prepara- 
tion was used for competitive binding assays according to Atassi and Saplin (17) but employing radioactive antigen to increase the sensitivity. The $\mathrm{P}-450$ cam labeled with $125 \mathrm{I}$ by the method of London et al. (18) retained about 95\% of the original catalytic activity. For studies on the inhibition of hydroxylation activity, the ammonium sulfate fractions of preimmune sera and antisera were submitted to column chromatography on DEAE-cellulose equilibrated with $0.01 \mathrm{M}$ phosphate buffer, $\mathrm{pH}$ 8.0. Benzphetamine hydroxylation in the reconstituted microsomal enzyme system was assayed both by NADPH oxidation at $340 \mathrm{~nm}$ and formaldehyde formation $(19,20)$. P-450 cleavage with $\mathrm{BrCN}$ (21) was carried out at $20^{\circ}$ in $60 \%$ formic acid in the dark for $72 \mathrm{~h}$. The resulting hemepetides were isolated by repeated column chromatography on Sephadex G-75 and DEAE-Sephadex A-25.

\section{Results:}

Immunochemical Experiments: Fig. 2 shows a radioimunoassay of competition of unlabeled $\mathrm{P}-450_{\mathrm{cam}}$ and $\mathrm{P}-45 \mathrm{LM}_{\mathrm{LM}}$ with ${ }^{125} \mathrm{I}-1$ abeled $\mathrm{P}-450$ cam for binding to anti-P-450 cam antibodies which offered sufficiently high sensitivity and accuracy to permit quantitative measurements. Under the conditions employed, the phenobarital-induced $\mathrm{P}-450 \mathrm{LM}$ exhibited 60 to $70 \%$ cross reactivity with rabbit antibodies elicited against $\mathrm{P}-450 \mathrm{cam}$. Furthermore, as shown in Fig. 3 , antibodies against $\mathrm{P}-450$ cam inhibited benzphetamine hydroxylation in the reconstituted microsomal enzyme system but were not as effective as antibodies against $\mathrm{P}-450 \mathrm{LM}$. In contrast, the corresponding $\gamma$-globulins of the

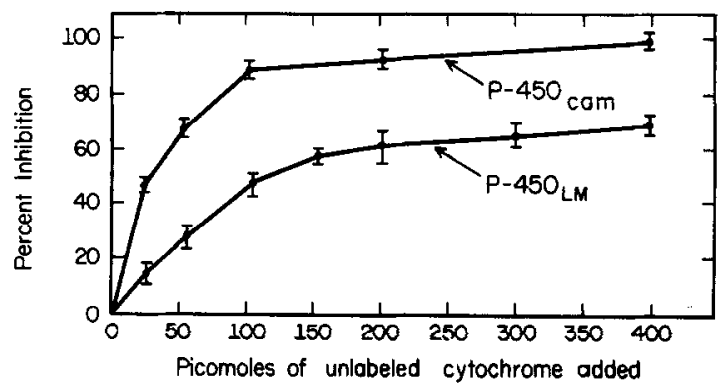

Fig. 2. Competition of unlabeled $P-450_{\text {cam }}$ or $P-450_{L M}$ with $1251-1$ abeled- $P-450$ cam for binding to anti-P-450 cam antibodies. To unlabeled antigen in $0.15 \mathrm{M}$ NaCl-0.05 $\mathrm{M}$ sodium phosphate buffer, $\mathrm{pH} .7 .5$, a constant volume of antibody was added to give a total volume of $0.30 \mathrm{ml}$. After a $2 \mathrm{~h}$. incubation at room temperature one equivalent of 125 -labeled $P_{-} 450$ cam, monoiodinated at five of its nine tyrosine residues, was added. After an additional $48 \mathrm{~h}$. incubation at $10^{\circ}$ the precipitates were collected by centrifugation, washed once with cold buffer, and dissoived in 0.2 $\mathrm{ml}$ of $0.2 \mathrm{~N} \mathrm{NaOH}$ for counting with the ${ }^{14} \mathrm{C}$ window in a Beckman liquid scintillation counter, Model LS-30. The inhibition of binding by purified $P-450 L M$ is based on maximal $P-450_{\text {cam }}$-anti-P-450 cam antibody binding normatized to $100 \%$. 


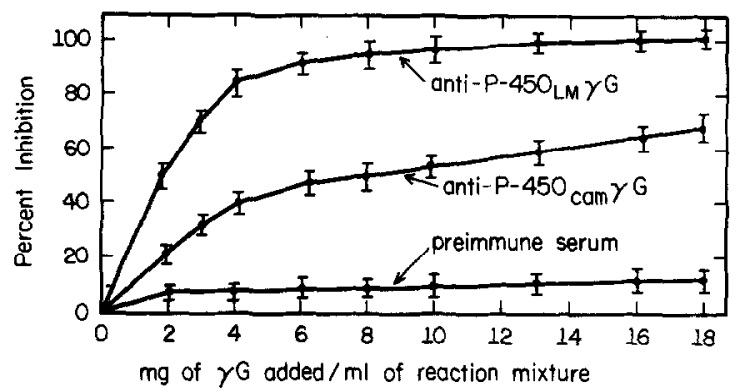

Fig. 3. Inhibition of benzphetamine hydroxylation by $\gamma-g$ lobulin fractions as measured by rate of NADPH oxidation in the reconstituted liver microsomal enzyme system. A mixture of purified P-450LM (0.4 nmole), purified NADPH-cytochrome $P-450$ reductase $(0.24 \mathrm{mg}$ of protein), dilauroylglyceryl-3-phosphorylcholine $(30 \mu \mathrm{g})$, HEPES buffer, pH 7.6, (50 umoles), phosphate buffer, $\mathrm{pH} 7.6$, ( 9 umoles), $\mathrm{MgCl}_{2}$ ( 5 umoles), benzphetamine (1 umole), and $\gamma$-globul in fractions as indicated, was incubated for 30 minutes at $22^{\circ}$. NADPH $(0.15$ umole in $0.015 \mathrm{ml})$ was then added to give a fixed volume of $1.0 \mathrm{ml}$, and the rate of the reaction was followed at $340 \mathrm{~nm}$ at $30^{\circ}$.

preimmune serum had only a negligible effect. The measurements of competitive binding with labeled antigen and of enzyme inhibition were employed in preference to the Ouchterlony double diffusion method because the detergents used to solubilize P-450 LM interfere with the latter procedure.

Size and Composition Similarities: Fig. 1 shows that the molecular weight of the polypeptide chain of $\mathrm{P}-450 \mathrm{LM}$ is about 49,000 daltons and that the preparation was about $90 \%$ pure; the primary contaminant is assumed to be the apo-P-450. The molecular weight of $P-450$ cam is about 45,000 daltons (15). The amino acid composition of the bacterial and liver microsomal P450 cytochromes shown in Table I was obtained from two series of experiments using total enzymic hydrolysis as well as acid hydrolysis before and after performate oxidation. The results must be interpreted cautiously but are compatible with the conclusions drawn from the immunochemical data that $P$ $450 \mathrm{cam}$ and $\mathrm{P}-450 \mathrm{LM}$ have common properties. Of particular interest is the occurrence of 6 half-cystines in both proteins; in $\mathrm{P}-450 \mathrm{cam}$ all six residues were found to be present as free sulfhydryls $(4,15)$, some of which are strongly implicated in the binding of the heme prosthetic group and the substrate (22). Other amino acid residues such as Met, His, Tyr, and Trp also correlate surprisingly well. The total of Pro, Gly, Ala, Val, Met, Ile, Leu, and Phe residues is 201 in $\mathrm{P}-450 \mathrm{cam}$ and 205 in $\mathrm{P}-450 \mathrm{LM}$. The high content of hydrophobic residues in both proteins is unusual. The slightly larger subunit of $\mathrm{P}-450_{\mathrm{LM}}$ is due to the additional amino acid residues and a larger 
Table 1

Comparative Amino Acid Compositions of Cytochromes

$$
\mathrm{P}-450_{\text {cam }} \quad \mathrm{P}-450_{\mathrm{LM}}
$$

\begin{tabular}{lrr}
\hline CySO & & \\
Asp & 6 & 6 \\
Asn & 27 & 21 \\
Thr & 9 & 14 \\
Ser & 19 & 23 \\
Glu & 21 & 26 \\
Gin & 42 & 24 \\
Pro & 13 & 19 \\
Gly & 27 & 24 \\
Alo & 26 & 30 \\
Val & 34 & 23 \\
Met & 24 & 27 \\
Ile & 9 & 8 \\
Lou & 24 & 19 \\
Tyr & 40 & 46 \\
Phe & 9 & 11 \\
His & 17 & 28 \\
Lys & 12 & 11 \\
Trp & 13 & 19 \\
Arg & 1 & $\sim 1$ \\
Total & 24 & 29 \\
Heme & 397 & 409 \\
\hline
\end{tabular}

Table 2

\begin{tabular}{lcc} 
Small BrCN & $\begin{array}{c}\text { Hemepeptides } \\
P-450_{\text {cam }}\end{array}$ & $\begin{array}{c}\text { of Cytochromes } \\
P-45 O_{L M}\end{array}$ \\
\hline CySO $_{3} H$ & 1 & 1 \\
Asx & 3 & 4 \\
Thr & 2 & 2 \\
Ser & 3 & 2 \\
Glx & 3 & 4 \\
Pro & 3 & 2 \\
Gly & 8 & 3 \\
Ala & 6 & 2 \\
Vol & 4 & 2 \\
Ile & 2 & 2 \\
Leu & 3 & 4 \\
Tyr & 1 & 1 \\
Pre & 2 & 2 \\
His & 1 & 1 \\
Lys & 2 & 2 \\
Arg & 2 & 2 \\
HSer & $\sim 1$ & $\sim 1$ \\
\hline Total & 47 & 37 \\
Heme & $\sim 1$ & $\sim 1$ \\
Soret Max & $390 \mathrm{~nm}$ & $397 \mathrm{~nm}$
\end{tabular}


amount of carbohydrate. The $\mathrm{pI}$ of 4.5 of $\mathrm{P}-450 \mathrm{cam}$ (15) is in agreement with the excess of acidic over basic residues, whereas $\mathrm{P}-450 \mathrm{LM}$, with fewer acidic than basic residues, should have a higher pI. Nevertheless, preliminary electrofocusing experiments indicated a pI for P-450LM that is even more acidic than that of $\mathrm{P}-450$ cam; this could result from acidic carbohydrate units.

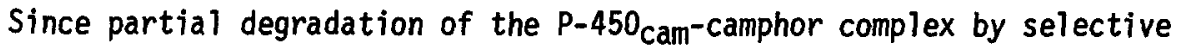
chemical cleavage with BrCN under carefully controlled conditions had yielded a small hemepeptide which could be purified by column chromatography without loss of heme (23), we applied the same procedure to $\mathrm{P}-450_{\mathrm{LM}}$ in the presence of phenobarbital and obtained an even smaller hemepeptide. It should be emphasized that a family of heme-containing peptides is generated under these conditions in each case and that the smallest is the one most readily purified. The amino acid compositions of the smallest hemepeptide from each of the two cytochromes is compared in Table II. Although the hemepeptide of $\mathrm{P}-450_{\mathrm{LM}}$ is smaller by 10 residues, a general similarity in composition is easily recognized. The occurrence of a single residue of histidine and cysteine in each hemepeptide is particularly striking. Our results therefore suggest a similarity in the heme region as well as in the overall structure of these two proteins.

Acknowledgement: Earlier suggestions by Dr. Muller-Eberhard and discussions with investigators of several laboratories concerned with monoxygenase cytochromes have contributed to the present work. We are particularly indebted to Professor I. C. Gunsalus, whose previous studies leading to the isolation and characterization of $\mathrm{P}-450_{\mathrm{Cam}}$, continuing interest, and generous advice were essential to the present studies.

\section{REFERENCES}

1. Hedegaard, J., and Gunsalus, I. C. (1965) J. Biol. Chem. 240, 4038-4043.

2. Katagiri, M. , Ganguli, B. N., and Gunsalus, I. C. (1968) J. Biol. Chem. 243, 3543-3546.

3. Peterson, J. A. (1971) Arch. Biochem. Biophys. 144, 678-693.

4. Yu, C-A., Gunsalus, I. C., Katagiri, M., Suhara, K., and Takemori, S. (1974) J. Biol. Chem. 249, 94-101.

5. Cushman, D. W., Tsai, $\overline{\text { R. }}$ L., and Gunsalus, I. C. (1967) Biochem. Biophys. Res. Commun. 26, 577-583.

6. Lu, A. Y. H., and Coon, M. J. (1968) J. Biol. Chem. 243, 1331-1332.

7. Autor, A. P., Kaschnitz, R. M., Heidema, J. K., van der Hoeven, T. A., Duppel, W., and Coon, M. J. (1973) Drug Metab. Disp. 1, 156-162.

8. Coon, M. J., van der Hoeven, T. A., Kaschnitz, R. M., and Strobel, H. W. (1973) Ann. N. Y. Acad. Sci. 212, 449-457. 
9. Levin, W., Lu, A. Y. H., Ryan, D., West, S., Kuntzman, R., and Conney, A. H. (1972) Arch. Biochem. Biophys. 153, 543-553.

10. Levin, W., Ryan, D., West, S., and Lu, A. Y. H. (1974) J. Biol. Chem. 249, 1747-1754.

11. Fujita, T., Shoeman, D. W., and Mannering, G. J. (1973) J. Biol. Chem. 248, 2192-2201.

12. Sato, R., Satake, H., and Imai, Y. (1973) Drug Metab. Disp. 1, 6-13.

13. van der Hoeven, T. A., and Coon, M. J. (1974) J. Biol. Chem. 249, in press.

14. Strobel, H. W., Lu, A. Y. H., Heidema, J., and Coon, M. J. (1970) J. Bio1. Chem. 245, 4851-4854.

15. Dus, K., Katagiri, M., Yu, C-A., Erbes, D. L., and Gunsalus, I. C. (1970) Biochem. Biophys. Res. Commun. 40, 1423-1430.

16. Laemm $i$, U. K. (1970) Nature 227, 680-685.

17. Atassi, M. Z., and Sapl in, B. J. (1968) Biochemistry 7, 668-674.

18. London, J., Livanov, T., and Greenwood, F. C. (1967) Biochem. J. 105, 1075-1083.

19. Lu, A. Y. H., Strobel, H. W., and Coon, M. J. (1970) Mol. Pharmacol. $\underline{6}, 213-220$.

20. Coon, M. J., Autor, A. P., Boyer, R. F., and Strobel, H. W. (1973) in King, T. E., Mason, H. S., and Morrison, M. (Editors), Oxidases and Related Redox Systems (Proc. 2nd Int. Symp.), University Park Press, Baltimore, p. 529-553.

21. Gross, E., and Witkop, B. (1961) J. Amer. Chem. Soc. 83, 1510-1511.

22. Harrison, J. E., Miguel, A. G., and Dus, K. (1973) Third PharmacologyToxicology Program Symposium, Washington, D. C., Abstracts.

23. Dus, K., Miguel, A. G., Smith, P. C., Litchfield, W. J., and Harrison, J. E. (1973) 9th International Congress of Biochemistry, Stockholm, Abstracts, p. 341 . 